\title{
Chapter 4 \\ Mediation and Conciliation in Collective \\ Labor Conflicts in Denmark
}

\author{
Hans Jørgen Limborg, Ulrik Gensby and Søren Viemose
}

The Case

\section{The mediation process, mediator role and outcomes}

One Danish company-we will call it 'Industry 1'-recently established a co-operative committee. The company employs around 400 people of which approx. 300 employees are organized in a trade union covered by a collective agreement, covering almost all blue-collar workers. During the first years of operating with the new committee structure the HR director and CEO experienced a long period of limited use and value of the committee. In the perspective of the CEO, the committee was known because of its name, and not from the merits gained from engaging in committee meetings and initiatives. The lack of use and differences in the perception of the value of The Co-operation Committee created frustration from both unions and management. The CEO and HR officer describe that they found themselves in a 'locked' situation, in which the relationship between the parties was characterized as an 'us' and 'them' relationship. The situation slowly escalated into a conflict of mistrust between the workplace parties, where the local unions lost faith in the management's ability to collaborate since they experience that the management came to meetings unprepared and were using The Co-operation Committee to inform about management decisions about changes in the workplace without inviting to have a dialogue around the content and consequences of the decisions being made. The unions argued that The Co-operation Committee was used in a wrong way, and that it was not an arena that the management could use to impose solutions. The management on the other hand argued that the committee meetings were

H. J. Limborg ( $\varangle) \cdot$ U. Gensby · S. Viemose

Copenhagen, Denmark

e-mail: hj1@teamarbejdsliv.dk

(C) The Author(s) 2019

M. Euwema et al. (eds.), Mediation in Collective Labor Conflicts, Industrial Relations

\& Conflict Management, https://doi.org/10.1007/978-3-319-92531-8_4 
unproductive and used to discuss minor issues and personal matters without consideration of the problems related to the work organization and production. Both the unions and CEO describe how they saw themselves in a position where they were not able to find a way forward. The workplace parties did agree that they needed help to take the next step. The Co-operation Consultants were then contacted. This contact lead to a joint meeting between the workplace parties that was facilitated by The Co-operation Consultants. At the meeting the consultants were used to set a common agenda for The Co-operation Committee based on a shared understanding of the purpose and specific function of The Co-operation Committee. In addition, the consultants worked with both parties to develop a set of principles that could guide productive discussions that were sensitive to the underlying interests of both parties in operating the committee, and that could help re-establishing trust between the parties.

One of the first issues being emphasized by the consultants was the rules for having and operating a co-operative committee (e.g. number of meetings, setting agendas, productive discussion guidelines, relevant issues etc.). This ensured a common knowledge ground that gave clarity around the goal and use of such committees in industry. Another issue raised by the consultant was the atmosphere around the committee meetings. By working concretely with the priorities to identify what types of collaboration areas that should be prioritized in the company and addressed during committee meetings, the meetings were given new status and mandate. As a result, the consultants put several work groups into action that should provide input to important areas of prioritization. These work groups were then followed up over time to ensure a continued relation between the consultants and the workplace. None of the workplace parties knew the co-operation consultants who facilitated the mediation process beforehand. The consultants were perceived as a neutral mediator-team that were able to get everyone on 'the same page', while they sustained a constructive tone during the facilitation of meetings and in mediating the different views about the motives for using the committee between the parties. The intermediary role of the consultants differed from the traditional mediator role. Rather the consultants took the role as a preventive facilitator, by taking part in the meetings and imposing structure and content to the discussions and brought the parties toward mutual understanding and win-win decision-making.

Rather than focusing on the initial positions reflecting the 'organizational dead-lock' around the co-operation committee, the workplace parties were guided towards common understanding of the situation and were given some simple and basic things to work with that could help them see things through a focus on the common interests of the company (e.g. collaboration areas that should be prioritized, and competitive position). The focus of the preventive facilitation was to re-establish trust and meaning with the discussions in the co-operation committee. Comprising how to perform good meetings, how to 
mediate and reach mutual understanding and avoid focusing on small and personal issues did qualify the discussion in the committee. Importantly, the establishment of work groups with participation of different representatives from the company has helped signal that the management is interested in the input from the workers and that the workers believe that the management will address these inputs and consider them when planning organizational changes. The work groups will provide specific input to three prioritized topics of collaboration; (1) company culture, (2) work retention and (3) the establishment of a new work site. Indeed, both parties develop new forms of interaction and are more capable of managing conflicts and negotiations, due to the mediation. One union member explains how he has become more aware of the management perspective and recognize their concerns although he does not always agree in their perspective. The HR officer recognize how the unions have become better at working with the management without getting stocked in a conflict approach. Both parties explain that a consensus orientation is important to move things forward. Thus, both parties have become more aware of listening to each other's concerns and the common interest of having a joint committee as an arena for addressing selected topics of collaboration.

\subsection{Introduction to Collective Conflict Mediation on the Danish Labor Market}

\subsubsection{The Danish Industrial Relation System}

The industrial relation (IR) tradition is often referred to as the 'Danish Model'. The model is based on a tri-partite social partnership between the Danish state, and employers' organizations and employee trade unions. The Danish IR system may be classified within the pluralist IR perspective, where of employer and employee subgroups are organized in associations and trade unions that act on behalf of their member interests to create co-operation, negotiation and facilitate compromise on employment terms (Salomon, 2000). Central to the Danish IR system is the substantial role that employers and employees play in influencing the combination of a flexible employment conditions, welfare schemes and labor market policies through collective bargaining (Scheuer, 1998). The Danish IR system is typically presented as four distinct features, including (1) close links between the social partners of the labor market and the state (2) centralized bargaining to conclude collective agreements between employers' and employee organizations, (3) a high rate of unionization among employees, (4) and collective agreements serving as a basic mechanism for IR regulation (Jensen, Madsen, \& Due, 1993). 
The Danish labor market is one of the most highly organized (Jensen, 2012). A high degree of organization is essential for the legitimacy and efficiency of the Danish collective bargaining system. In 2015, the percentage of employees organized in trade unions were $67.7 \%$. With a coverage rate of $80 \%$, the collective agreements are ranking comparably higher than seen in other EU Member States. The coverage rate stood at $85 \%$ for several decades and has been relatively stable up until 2010 . However, in recent years the coverage rate has tended to decline. Today the coverage rate sits at $71 \%$ in the private sector and $100 \%$ in the public sector (Denmark Statistik, 2018).

Although described as a tripartite structure, the Danish state and political system usually take a relatively limited role in IR regulation, and rely on the ability of the parties to reach an agreement on their own (Jensen et al., 1993). Any collective agreement is binding in accordance with the basic agreements reached between the social partners in the private as well as public sector. Approximately $50 \%$ of the private employers are organized with the most comprehensive organization being the Confederation of Danish Employers.

In contrast to other European countries, the Danish IR-system includes an important normative and political alignment with a preference for IR regulation via collective bargaining and agreements, rather than regulation through individual contracts and legislation (Jensen et al., 1993). The convention being that trade unions, private employers, and public employers form an agreement on wages and other working conditions, and that the parties are accountable in relation to these agreements. Quite many non-organized private employers join these collective agreements. Consequently, the legislation, which consists of rules applying to certain groups of employees (e.g. regulation of salaried workers) as well as to specific matters (e.g. regulation on holidays) is of minor importance compared to some other countries.

\subsubsection{Institutional Background and Historic Compromise}

The Danish IR system-orientation of collective agreements traces its origins to a series of industrial disputes between employers and employees, also referred to as the 'September Compromise', 1899 (Jensen et al., 1993). The Danish IR system of collective agreements has evolved as a system, that builds on centralized collective bargaining negotiated at the main organization-level. This historical development has ensured a relatively high degree of homogeneity, regarding pay and employment terms. However, a turn in the Danish IR system has shifted the collective agreement system towards more 'centralized decentralization' (Andersen \& Mailand, 2005). Importantly, every sector on the Danish labour market have combinations of flexibility and security, but not all employees are covered by both flexibility and security to the same extent (Mailand, 2009). Decentralized collective bargaining give employer and employee representatives increased opportunities to negotiate employment terms at the workplace level (Blanplain, 2007). In 1908, a government body formed the basic principles for the solution of conflicts about collective agreements; and a dis- 
tinction was drawn between 'conflicts of interests', where the matter in dispute is not covered by a collective agreement, and 'conflicts of rights'.

In 'conflicts of interests' the parties are free to take collective industrial action (strike or lockout); but when a collective agreement has been concluded, they are under an 'obligation of peace' if the agreement is in force. An alternative procedural system has been set up, and a 'conflict of rights' must be settled through negotiations at either the local, the organizational or the central organizational level. If the dispute is not resolved in this way, a dispute concerning the interpretation of the agreement must be referred to industrial arbitration and a dispute concerning a breach of the agreement must be brought before the Labour Court. The Labour Court is thus the main dispute-resolving body in relation to labour market conflicts. It has existed since 1900 and was established as a proper court of law named The Permanent Court of Arbitration in 1910. There are special rules concerning appointment of judges and powers, as the social partners are involved in this process. Since 1964 it has been named the Labour Court. The regulation has been updated several times and the newest act on Labour Court was passed in 2008 (http://www.arbejdsretten.dk/ generelt/labour-court.aspx).

\subsection{Characteristics of the Danish Collective Mediation System}

\subsubsection{Negotiations on Different Levels-The Ladder of Conflict Resolution}

The Danish collective mediation system is based on two essential pillars; (i) the right to use conflicts in terms of strikes or lock-out when settling a general agreement, and (ii) 'the obligation to peace', when the agreement is in function. A key feature of the Danish conflict resolution system is that none of the parties can refuse to participate in meetings with the aim of settling a conflict, whether it be a matter of dispute of interest or right. This is stated in 'The rules for the Hearing of Industrial Disputes' adopted by the Employers' Confederation and the Danish Federation of Trade Unions and the Rules for the Hearing of Industrial Disputes' also referred to as 'the Norm'. The existence of the special negotiation procedure means that only a minor part of this type of conflicts are continued before judicial dispute-resolving bodies, and it would normally be regarded as a breach of agreement if a party fails to participate in conciliation (Limborg, Jørgen, Albertsen, \& Navrbjerg, 2014).

The first step in conflict resolution is to reach for a local agreement on the issue, through negotiations between the employee representative (union) and the management. The negotiations must be documented and of course the take their point of departure from any existing agreement. In the event of failure to settle the dispute by local negotiation, the allegedly injured party will submit a petition for conciliation specifying the subject of the dispute. The second step will then be the setting-up of a 
conciliation committee, normally each party (Union and employers' association) to the agreement will appoint a member each. The conciliators need not be impartial, but they may not, however, have any personal interest in the matter to be considered. The discussions with the committee are rather informal and should take place on the firm's premises. In this case, the employee representative and the manager are participating as observers. The organizations of the social partners or their appointed conciliators will lead the process. The result of the conciliation is forthwith committed to a minute book, and if the conciliators are unanimous the committee may settle the dispute once and for all at variance with the wishes of the parties directly involved. If the conciliation is ended without a result, the consideration of the dispute may be continued to the third step: a 'meeting of the organizations'. These meetings are usually attended by several representatives from each organization and, as in the case of the conciliation committee, the board of negotiators may decide the matter if unanimous.

Most conflicts are resolved within these first three steps. An important element of the stepwise procedure - as it is described in "the norm"-is that all parties are committed to act as fast as possible. In situations where time is of the essence, it is even possible to use an alternative procedure, 'the joint meetings' where everybody, including representatives of the central organizations, participate at the same time. The flexibility of this system and the ability to act fast and bring forth solution to as well trivial as more complex matters, is one of the important strength of the system, and the reason that it is still considered extremely successful even after more than 100 years.

\subsubsection{Industrial Arbitration-The Fourth Step}

In more complex cases where the mediation sought for in the first three steps is not reached, the case will be brought to 'Industrial Arbitration'. The industrial arbitration tribunals are not covered by the general Arbitration Act but are governed by the Labour Court Act and provisions in the Rules for the Hearing of Industrial Disputes adopted by the Employers Confederation and the Federation of Trade Unions or similar general agreements as well as stipulations in the collective agreements in question. These are usually modelled after the Rules for the Hearing of Industrial Disputes. Usually the arbitration tribunals are set up for hearing a single, already existing case, in which case each party normally appoints 2 arbitrators and the President of the Labour Court one (or in some cases 3) umpire(s) (opmand). Anybody could be appointed as arbitrator if they have no personal interest in the matter. Most often the umpire is a judge with experience from labor disputes appointed from a small circle of legal professionals.

A special area for the industrial arbitration tribunals involves cases concerning dismissals of employee representatives (union), pleading that the dismissal was non-objective. Furthermore, some agreements contain provisions that refer cases to arbitration on a general basis, and, besides, it frequently occurs that the parties specif- 
ically agree to have the industrial arbitration tribunal consider the matter of breach of agreement about the question of interpretation. A few permanent industrial arbitration tribunals exist, such as the permanent Board of Dismissals, which was set up in accordance with the General Agreement between the Employers' Confederation and the Federation of Trade Unions to decide cases involving non-objective dismissals.

The industrial arbitration tribunals are concerned, first and foremost, with disputes over the interpretation of the collective agreements, which the parties have been unable to resolve, by negotiation in accordance with the agreement. It is considered as a breach of agreement, if a party fails to co-operate in the implementation of the arbitration proceedings. The industrial arbitration tribunal is presided over by the umpire, and the actual presentation to the tribunal is done verbally and in principle in the same manner as before the ordinary courts of law. However, the representatives of the parties are not always lawyers, and the hearing can be rather informal.

\subsubsection{The Labour Court}

If a dispute relates to a specified violation of an agreement, the conflict resolution will follow another path, first step again being local negotiations and further a meeting between the central organizations and a final option of being taken up by the Labour Court. The Danish Labour Court is a special court of law. The Court is seated in Copenhagen, but the jurisdiction includes the whole country.

Cases can only be brought by and against the relevant employers and employee organizations, regardless of whether the breach was committed by or against single members of either organization, or the collective industrial action was threatened or commenced by or against single members of either organization. Where an organization is a member of a comprehensive organization, the case must be conducted by and against the latter.

In recent years, less than 20 cases per year were subjected to a full-court hearing. A somewhat larger number of cases about 100 per year, were concluded by the parties entrusting the decision to the judges who considered the cases in the preliminary meetings.

\subsubsection{Procedure of the Court}

When court is held by the President, one of the vice-presidents or in certain cases the Head of Secretariat alone, the parties (each represented by a comprehensive organizations) exchange complaints and defenses pleas and additional pleas. The judge may ask the parties to obtain further statements or information, and the case may, if necessary, be postponed, setting a later date for a preliminary meeting. This procedure includes an investigation of a possible amicable solution, in a clear majority of cases the parties manage to reach a settlement—-sometimes through the intervention 
of the judge and are thereby concluded. If the judge can ascertain that it is impossible to reach an agreement between the parties, a date and time is set for a full-court hearing.

After the parties, have presented their case follows the examination of possible witnesses. Immediately after the hearing the Court will discuss what is to be decided and to give their votes. Before this final meeting is held, the presiding judge draws up a draft of the decision and copies of the draft sent to the other members. The decision is drawn from the traditions of the Danish civil law. Finally, the conclusion of the Court is specified. The decision and the final wording are adopted from the majority votes, and the presiding judge pronounces the decision publicly in the courtroom.

\subsubsection{The Ability to Handle Urgency}

Pursuant to the Labour Court Act strikes or lockouts in contravention of a collective agreement must immediately be reported to the organizations, and a joint meeting attended by the organization must be held the day after the beginning of a strike or lockout. When a current industrial action is brought to the Labour Court, the case will be considered as a case of urgency. As a rule, the presiding judge will appeal to the members of the organization to comply with the request of their organization.

If the members of the organization do not comply with such a request immediately, the fine, which they are to be imposed because of the action, will increase considerably. If the Court cannot deal with all the problems of the case immediately, it can at the end of the hearing deliver an interlocutory order declaring the industrial action in contravention of the collective agreement. If the industrial action is no longer on-going when the case is brought to the Court, the case will be handled as a non-urgent case (Limborg, Jørgen, Albertsen, \& Navrbjerg, 2014).

\subsubsection{Resolution Before It Ends in Court-Decisions During Preliminary Meetings}

In a substantial number of cases the parties and the judge at the preliminary meeting will agree that the matter is not of such a nature as to justify a full-court hearing. If so, evidence is produced at this point or at a subsequent preliminary meeting open to the public and, in conclusion, the parties will present a brief oral review of their points of view. The resolution of the case is thereafter entrusted to the President, vice-president or in certain cases the Head of Secretariat, who is required to meet the general conditions of being a judge and in fact has always been a district court judge. In most cases the judge will promptly deliver and explain the result, which is recorded in the records of the Court. This marks the conclusion of the case (Fig. 4.1). 


\subsubsection{Additional Third-Party Involvement, and Workplace Co-operative Institutions}

Alongside the formalised procedures for labour market conflict resolution, arbitration and labour court, other third parties and less formal institutions guidance and consulting on conflict resolution to companies and institutions. There is a minor private market of consultants offering mediation and conflict resolution to companies, institutions and unions and associations. These services might be growing, however currently there are no available public register or statistics to estimate the development of the private conflict resolution services available, or even to provide an overview of the approach that private consultants would apply. One way to identify private consulting firms and services offered in cases of collective conflict resolution is to perform a Google search. When judging the suite of services and approaches identified a common understanding of conflicts and their resolution is to focus on the interpersonal relations with little or no consideration of the formalised collaboration structures in the workplace.

\subsubsection{The Co-operation Agreement}

One of the more formalised institutions used for systematic co-operation between employers and employees at all levels is the 'The Co-operation Agreement' between DA (the Confederation of Danish Employers) and LO (the Danish Confederation of Trade Unions). 'The Co-operation Agreement' was first concluded in 1947 and has since been modernized on a continuous basis and, most recently, in the current agreement which dates to 2006.
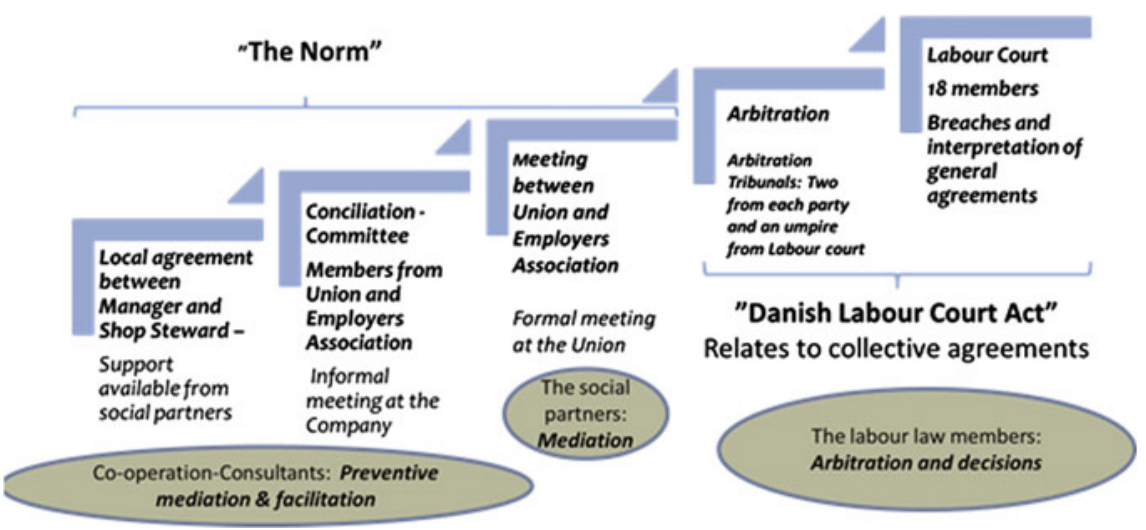

Fig. 4.1 The ladder of conflict resolution on the lowest possible level between agreements 
'The Co-operation Agreement' defines the institutional framework for cooperation and social dialogue between the employees and management in all the companies that are members of The Confederation of Danish Employers and contains rules for mutual information on working conditions for employers and employees. 'The Co-operation Agreement' also contains the supplementary agreement on equal treatment and integration as well as the supplementary agreement on Telework. The Co-operation Agreement implements the EU-regulation on information and consultation.

Importantly, The Co-operation Agreement' is operating within the industrial sector, but a similar institution, with a little variety, has been developed as an offer to organizations where the state is the employer. Thus, municipalities and regions (The health care sector) are excluded from such an offer. The institutional framework laid out by the Co-operation Agreement includes three ways to support the day-to-day cooperation and interaction between management and employees; (1) The Co-operation Board, (2) Co-operation Committees, and (3) Co-operating Consultants.

\subsubsection{The Co-operation Board}

The secretariat supports management and local employee representatives (union) in all matters of co-operation. The board consists of 7 members that represent employers and employees. The following duties summarizes the work of the board (Samarbejdsnævnet, 2006):

1. Provide information, guidance and development for promoting workplace cooperation

2. Assist in establishing co-operation committees and guiding them in their activities

3. Constitute a forum for conflict resolution and mediation in cases of disputes.

When meeting with local Co-operation committees the board secretariat is represented by co-operate consultants from both the employer and employee side.

\subsubsection{Co-operation Committees}

In companies with more than 35 employees or more, the day-to-day co-operation should be promoted and observed by a co-operation committee composed of representatives from management and employees. In accordance with 'The Co-operation Agreement', the co-operation committee should consider and determine how the committee can promote and coordinate co-operation between management and employees at all levels of the organization. 
To ensure the establishment of principles both management and employees are required to actively commit to achieving an agreement by joint consultation and to implement the agreed upon terms in practice. The co-operation committee is free to coordinate its work based on the needs and wishes of the local context if the main aim of the 'The Co-operation Agreement' is in focus, and the work of the committee are observed and complies with the obligations of the agreement. The committee may seek advice from the Co-operation Board if needed. In cases where local committees do not comply with 'The Co-op-operation Agreement' both management and employee representatives have the right to demand a renegotiation of principles and/or terminate the committee and agreed principles.

\subsubsection{Co-operation Consulting Units}

We have chosen to describe the joint initiative offered by The Confederation of Danish Industry (DI) and Central Unions from-Industry and Food, and Allied Workers' Union (CO-I and NNF) to help companies improve the daily co-operation between management and employees and resolve collective conflicts at the workplace level. A unique possibility, within the co-operative structure of DI and CO-I, is the opportunity for employers and employees to call for the co-operation unit in cases of dispute or conflict resolution at the workplace. 18 consultants work in co-operative units and are trained to visit companies and provide advice on the establishment of co-operation committees, dispute resolution and cooperative development in association with the introduction of new technology or improving psychosocial working environment.

The counselling of the co-operation unit takes place within the framework of the two co-operation bodies TEKSAM (Committee for Technology and Co-operation) and FTS (Committee for the Food Industry and Technology Co-operation), which administrates the 'Co-operation Agreement'. TEKSAM consist of elected politicians who assist the collaboration between DI and CO-I. TEKSAM recognises the co-operation unit and can assist in situations where the co-operation consultants cannot re-establish trust and collaboration between the local workplace parties. TEKSAM will then perform a 'second hearing' in cases where it is not possible to reach compromise or agreement (Fig. 4.2).

An interesting new development among the social partners in the public sector is a trend to include funding to establish and realise consulting units-with to aim to support co-operation at workplace level —in the general agreements. The support is primarily focused on developing a healthy psychosocial working environment and in resolving local conflicts in cases were either side has violated the collective agreements. Such units are currently being established in the municipality sector, in the health care and hospital sector (regions) and in the workplaces of the state. 


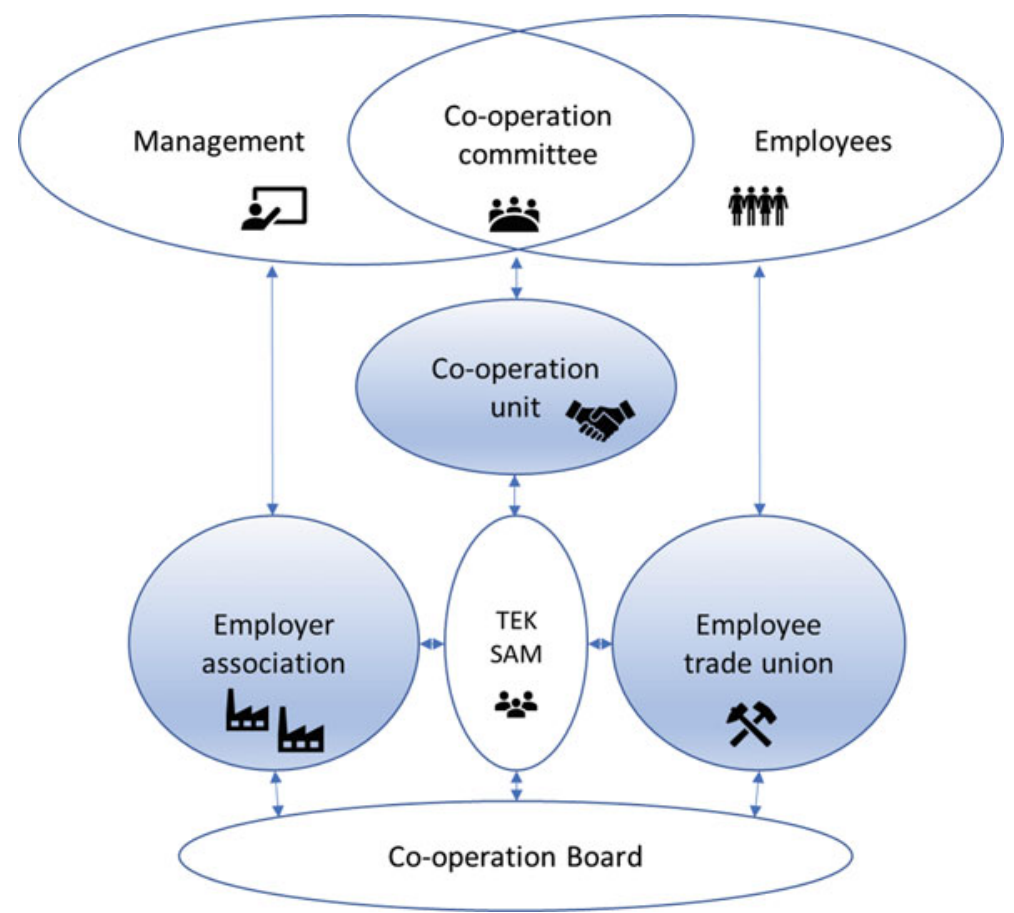

Fig. 4.2 Collaboration structure of the co-operation unit

\subsubsection{Stakeholders' Evaluation of the Formal Mediation System and Services}

Looking at how parties at company level in the Co-operation Committees and at administration and union level perceive the Danish collective labour mediation system the following issues are found to influence the effectiveness of the mediation services provided:

- As a Co-operation consultant as well as a private mediator it is important to have indepth knowledge about the Danish model and to value and understand the interest from both parties involved and that both of their interest must be represented, and that this representation is best taken care of through an active collaboration between employers and employees. Often it takes a lot of experience to reach the ability to facilitate and de-escalate conflicts in a timely and respectful manner.

- One limitation to the Co-operation consultants is their limited ability to gather more thorough data and to produce evidence-based and reliable analysis of this data, when a deeper understanding is required to unfold the background of a conflict. In this case private consultants offers a better opportunity. 
- The Co-operation consultants are recruited from different disciplinary backgrounds and have gained personal experience in consultancy, mediation and conflict resolution. A common feature of their role in the system is a value-based approach to social dialogue that emphasize humanization instead of authority since a key competence is not to take sides, but to navigate and meet the conflicting parties with respect for their point of departure.

- A common critical issue is that management is very nervous to lose the managerial right when establishing a Co-operation committee, which is something that the consultants work very hard to diminish. Rather the point is that The Co-operation Committee can be an important catalysator for legitimizing the management decisions. To establish this understanding will often be an important first step for the mediators.

- The mediators experience that the system allows them to be consistent in the way they deliver the mediation services and answers during the mediation process. They rely on a high degree of trust in the system, but simultaneously they are continuously evaluated in terms of their ability to act legit and correct according to this.

- Interestingly the Co-operation Consultants do not measure their success from the level of satisfaction from users but from their own ability to maintain the use of the co-operation institutions locally and on institutional level. Particularly Danish companies that has been taking over by international businesses, represent a challenge as these companies do not bring in knowledge and experiences from using the co-operation institutions in the Danish Model. In these cases, it is critical to make them understand how it is possible for employers and employees to decide on collaboration areas that should be prioritized and reach consensus on their implementation in practice.

\subsection{Characteristics of the Mediators or Facilitators and the Third-Party Procedures}

The co-operation unit is a free service available to members of DI. The costs of having co-operation consultants involved in conflict resolution at the workplace is covered by the DI membership fee of the company. The co-operation unit offer help and facilitate conflict resolution independent of the company location. Currently, no accreditation system exists to monitor or train the co-operation consultants in Denmark. There is no specific profile connected to the consultants working for the co-operation unit. Typically, the consultants are recruited from different backgrounds, but all consultants have experience with workplace consulting and conflict resolution. However, a range of skills, competencies and extensive experience is useful. Cooperation consultants need in-depth understanding of the structure of the Danish labour market, and the mechanisms of the Danish IR system in combination with an ambition to strengthen the current IR system. In addition, the ability to understand 
how to represent interest from both 'sides of the table', from the view that these interests are best presented through joint labour and management collaboration, is important.

Another essential competence is the ability to create a feeling of community and common action to move the conflict situation towards a resolution. Here human value skills are needed to facilitate negotiation and achieve commitment and compromise in dispute situations. In sum, the competence profile of the co-operation consultants is very much related to the ability to facilitate, humanize and de-escalate conflict situations. The co-operation units work from a social dialogue and system theoryoriented approach to understand the conflict, and to simplify issues related to the dispute situation. The approach is relational and not individual, in the sense that the consultants look at the relations between the levels of the organization to clarify potentials of collaboration. Here the focus is to give advice and guidance in both the creation of co-operation committees as in issues concerning their daily co-operation.

The co-operation consultants work with the co-operation committees to deal with locked conflict situations in companies, including the improvement of the cooperation practise and culture. Importantly, the task of the co-operation consultants is not to resolve the conflict, but rather to get an understanding of the different interests, and to re-create trust between the local parties. The co-operation unit is always a team from the trade union and the employer association behind the joint initiative. The consultants always work in pairs to underline the idea of joint representation, which also help ease their presence. The task is then to show the local parties how the co-operation consultants collaborate, and that it works.

The consultants do not meet with local workplace parties separately. Importantly, the rationale for their involvement is to avoid creating dependency on the consultants to resolve the conflict but providing the needed help to the parties without overtaking the company and the conflict situation. The co-operation consultants do have methods that they use across settings, but currently no standards exist to guide the conflict resolution process. Instead the co-operation consultants work from the approach that every company is a unique setting, and that applying standards can risk blurring the contextual understanding of the conflict situation.

\section{At What Stages are the Conflict Mediation System Active?}

1. Preventive facilitation (Before conflicts): Training of employee representatives (union) and managers. Co-operation consultants are supporting cooperation committees to be able to prevent conflicts to occur.

2. Latent conflicts and early stage: Local co-operation committees supported by union representatives and management act as facilitators.

3. Confrontation: Trade unions and employer associations take over.

4. Hot conflict: Arbitration or labor court.

5. Rebuilding working relations: Co-operation consultants facilitate restoring co-operation committees and local collaboration. 


\subsection{Description of the Facilitation and/or Mediation Process}

Typically, workplace disputes arising from local disagreement about interpretations of the Co-operation Agreement should be resolved by means of the co-operation committee. During the dispute resolution either party is entitled to seek advice from TEKSAM and the co-operation unit to help resolve the dispute and take up negotiations. Figure 4.3 illustrates the typical steps of a conflict resolution process in which the co-operation consultants are involved. Each step is described in detail below.

1. The process starts when the co-operation unit is contacted by a company, which experience a conflict or violation of a collective agreement. Both management and employee representatives on the co-operation committee can take the initiative to ask for and obtain advice from the co-operation unit. When the need and conflict issue has been clarified, a preparatory meeting is scheduled between the co-operation consultants and the management and employee representatives from the company.

2. The aim of the preparatory meeting is to survey the conflict situation and discuss initiatives to act. The preparatory meeting represents a specific intake procedure which allow the co-operation consultants to get a deeper understanding of the conflict by listening to the arguments and frustrations of both parties. At the preparatory meeting the co-operation unit meet up with representatives from both DI and CO-I. The co-operation committee from the company appoints the participants for the preparatory meeting and the following seminar.

3. Following the preparatory meeting the co-operation consultants will draft the content of the seminar, including a program description and presentation of the methods that can facilitate social dialogue and conflict resolution. There is no pre-specified protocol.

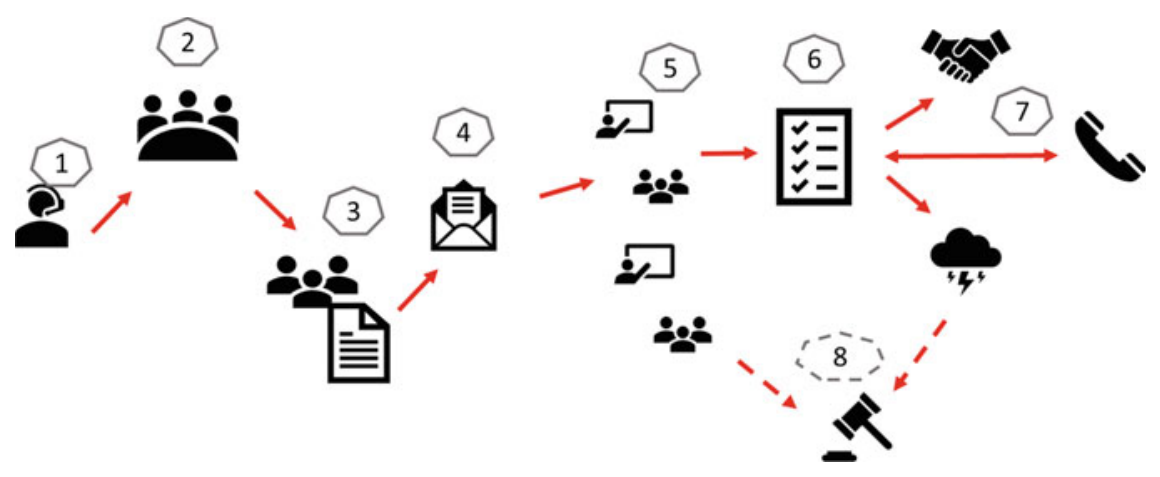

Fig. 4.3 Illustration of the conflict resolution process at the organizational-level 
4. Once the content of the seminar program is drafted, the program is send to the company for approval. The chairman and vice-president of the co-operation committee then makes a judgment on the program and develop ownership of the project.

5. If the program is accepted by the company, the seminar will take place. If the parties cannot agree on the first seminar they may agree to plan a follow up seminar to reach a compromise. The seminar process may focus on some or all the following issues:

- When the co-operation consultants' visits companies, the consultants typically start by outlining some points to arrive at, referring to the core principles of 'The Co-operation Agreement'. The underlying aim is to establish common ground for joint interests.

- The management is told to repeat what the employees say even though they disagree. This to indicate that the management have listened and are not shifting their frustrations on the employees.

- The parties are encouraged to reflect on the tasks and responsibilities of the co-operation committee in resolving the conflict and/or as a change facilitator.

- Some globalized businesses may need assistance to understand the Danish labour market and the tradition and culture of collaboration.

- All participants have veto power without justification, which means that all parties can express their concerns and dismiss an initiative they do not want to be part of.

6. Seminars are recorded and summaries in a common report drafted by the cooperation consultants and send to the company co-operative committee. Specifically, the report includes a summary of the negotiation process, and action items.

7. If trust is re-established between the parties, and the parties can agree on the content of the seminar report, a compromise can be reached. If the dispute cannot be resolved, or it is impossible to reach a formal agreement, either party can bring the matter to TEKSAM with a description of the dispute and a summary of negotiations process. TEKSAM will then try to reach a settlement and involve the employer associations and trade unions of the parties.

8. Should the parties refrain from any settlement, the Co-operation Board can appoint and industrial arbitrator. In complicated cases the arbitrator is appointed by the chairman of the Industrial Court. The Co-operation Board deal with the specific case in accordance with the procedures of industrial arbitration. If the case is not settled during board proceedings, a potential ruling will be made. If the case is found to violate the Co-operation Agreement, the party in breach can be held liable to pay a penalty (Samarbejdsnævnet, 2006). 


\section{Quick Overview of the Conflict Mediation Process}

1. First step in conflict resolution is to reach for a local agreement, through negotiations between the employee representative (union) and management.

2. Second step is setting-up of a conciliation committee; normally each party (union and employers' association) to the agreement will appoint a member.

3. Third step: If the conciliation is ended without a result, the consideration of the dispute may be continued with a 'meeting of the organizations'. These meetings are usually attended by several representatives from the organizations on both sides and, as in the case of the conciliation committee, the board of negotiators may decide the matter if unanimous. Most conflicts are resolved within these first three steps, and all parties are committed to act as fast as possible.

4. Fourth step: In more complex cases where the solution sought for in the first three steps through mediation is not reached, the case will be brought to 'Industrial Arbitration'.

5. If a dispute relates to a specified violation of an agreement, the conflict resolution will follow another path, first step again being local negotiations and further a meeting between the central organizations and a final option of being taken up by the Labor Court.

\subsubsection{Stakeholders' Evaluation of the Mediators and Mediation Process}

The following motives were identified for using the co-operative institutions and mediation services provided by The Co-operation Consultants:

- A common motive for using The Co-operation Consultants relates to differences between workplace parties in the interpretation of collective agreements. In one case a company had disagreements about, which things they should consider in relation to the establishment of a new Works Council (co-operative committee) an issue was if all parties should be unionized. This issue was discussed on a mediation meeting with the union, and the chair of The Co-operation Committee and co-operative consultants. Following the meeting the consultants were invited to monitor the process of the meeting to support the procedure and evaluation. Having the consultants as participants were relevant to help new committee members to decide which concrete issues were suitable to address in the committee and how.

- Another motive relates to situations where the dialogue between the workplace parties is locked. One case reported that the situation between the parties were characterized by an 'us' and 'them' relationship. The Co-operation Consultants 
were used to guide productive discussions from a shared understanding of the purpose and specific function of The Co-operation Committee as an arena for social dialogue at the workplace level.

- The Co-operation Consultants are also used to help facilitate meetings about the interpretation and action planning of health and safety audits done at the workplace. In one case the company used The Co-operation Consultants to summarize discussions points and suggestions from the meeting, and what agreements were reached for the company to enhance preventive initiatives related to the psychosocial work environment.

- Yet again, a central motive relates to situations in which there is a history of distrust between the parties at the workplace. In these cases, The Co-operation Consultants are used not only to facilitate discussions on the problems related to the way the dialogue work between the parties, but also to impose a structure and mediation process that is designed to help mutual trust building between the parties and win-win agreements.

\subsection{Possibilities to Increase the Use and Quality of Social Dialogue and the Mediation Provided}

The mediation service of the Co-operation Consultants is utilized in specific clusters of the labor market. Companies that have gained knowledge of the possibility. The overall knowledge about The Co-operation Consultants among the Unions is poor. The unions on their side wish for more information about how to get in touch with the consultants when facing a conflict situation. The unions believe that it is important to increase awareness and information about the resources of The Co-operation Consultant prospectively to help prevent conflicts at the workplace level. One union member suggest that it is mandatory for every new union member to attend a course about the principles and practices of the co-operation institutions and consultants, as many newly elected employee representatives (union) use their first year to get familiar with the mediation system and the mediation resources. In, addition some companies request that the consultants are more proactive in approaching The Cooperation Committees in the companies directly. Both HR officers and unions agree that many companies could benefit from having some form of interaction with the consultants about the use of co-operation committees and/or interpretation of collective agreements to help support joint employer and employee collaboration. In some cases they even suggest that it would be relevant to install mandatory process for companies that were covered by the collective agreement, in which they interacted with the consultants about their role and resources in connection to a self-imposed subject. Such a meeting is proposed to take place every fourth year to keep the interaction up to speed and ensure that the right competencies and knowledge are in place in situations with replacement of management and/or unions in The Co-operation Committee. 
The availability and existence of the very limited group of private mediators is also only known to a limited number of institutions and companies. Mostly they seem to be used by the larger Unions and Employers Associations, and more rarely by private companies.

\subsubsection{Ideas for Improving the Use and Quality of the Mediation Process and Social Dialogue}

Importantly, some companies anticipate that there will be a more specialized need for mediation processes in the future, since many modern organizations need knowledge and input about how to manage complex organizational changes, and how to address this as a collaborate issue being discussed in the co-operative institutions. In other cases, management assess that there will be an increased need for inter-sectorial collaboration between the various parties involved in mediation processes to help maximize the use of resources and create long-lasting solutions. Thus, a key concern for the quality of the mediation provided is whether The Co-operation Consultants can maintain the high level of mediation, in a situation where the labor market becomes more and more complex (e.g. new employment relations, new forms of EU regulation that could decrease the flexibility on the Danish labor market).

According to The Co-operation Consultants the main concern is to be conscious about the monopoly of their assignment in the sense that they are provided with a responsibility and a huge obligation to promote social dialogue at the workplace. In their perspective, it is their awareness and focus on this responsibility that determines if the mediation will survive or not. In addition, it is a very narrow system with a constant development dynamic, which demands a continuous openness and connectivity to research and other parties in the system to avoid being stuck with old methods and lack of coordination with other relevant initiatives. Providing a development field for more fact-based mediation and for mediators or mediating institution that combine process facilitation with knowledge-based analysis and fact-based conflict illumination.

\subsubsection{Stakeholders' Evaluation of the Effectiveness of the Mediation in Organizations}

The co-operation consultants experience a high degree of satisfaction from companies regarding the workplace conflict resolution process. The high satisfaction and legitimacy of the co-operation consultants is based on their efforts to act consistently and provide consistent answers when facilitating social dialogue and conflict resolution. In general, the Danish IR system is characterized by authority and a high level of social trust between the parties, and a belief in the ability of the IR system to 
reach compromises and promote negotiation. As such, the idea that employers and employee can find common ground and work together to reach joint solutions and compromise is central for understanding the consistency and success of the Danish IR system. In this situation, it is critical for the co-operation unit to constantly be aware of their duties to take joint responsibility, if not the balance of the Danish IR system may be challenged.

In both cases, all participants expressed that they valued the opportunity to use external mediation either through The Co-operation Consultants or the private mediation services that they provided. The following reasons were given to exemplify the satisfaction with the mediation services provided:

- The mediation systems (as well Co-operations consultants as private mediators) were characterized by a willingness to renew themselves and thoroughly understand the concrete context of the potential conflicts. They were able to provide up to date support in terms of areas of importance to the workplace parties, as well as the more political actors in the municipality. They understood conditions in the sectors and they were up to date on regulation and agreements. This was considered important to bring the parties in a position to work with the challenges they face in practice rather than read a conflict as emotional. All the mediators proved to have specific knowledge about the Local Co-operation institutions, collective agreements and relevant regulation, it is an advantage to have the ability to give a clear answer to questions about how to interpret collective agreements.

- An advantage of the mediation system based upon The Co-operation Agreement is, that The Co-operation Consultants always operates in pairs of consultant representing both the trade union and the employer association. According to several cases, this signals a common ground upfront when starting a mediation process, that emphasize the joint commitment between employer and employee side to resolve the situation and strengthen the trust in the facilitation and mediation provided.

- An advantage of the private mediators was for the professional process facilitator a large experience of creating an open process and create trust among the parties. The fact-based mediator group had the scientific capacity that made them able to present thorough data that both parties found evidential and reliable.

- All three types of mediators are recognized as trust worthy for their effort in balancing common goals, and to communicate the interests of both parties involved in the mediation. This is important since several cases did experience situations in which disagreements between workplace parties becomes personalized, and the consultants tried to raise awareness to the organizational issues and common interests.

- Lastly, several cases appreciate the quick response from the time that a company contact the mediator-whether it is The Co-operation Consultants or the private mediators-and to the actual presence in which the consultants sit down together with the workplace parties to have them explain their views to each other about the nature of the problem and how they think it might be resolved. Creating trust is also a matter of timing, timeliness and precision. 


\subsection{Conclusion}

\section{Overall Evaluation of the System}

- The Danish co-operation mediation system is based upon the more than 100year old Co-operation Agreement. It has developed into a type of support system that is based on collective agreements, and work as the first step of the conflict resolution steps included in the Danish Model.

- A key feature of the mediation system is that third party co-operation consultants work together in teams providing mediation services, which installs a joint problem-solving focus in mediation processes at the workplace level. This is different from training individual conflict mediators and relying on individual person's skills and approach to mediation.

- Outside pressures. Politicians might interfere with the system to regulate a conflict situation. This can create a negative trickle-down effect in the system, in which co-operative institutions and workplaces are not given the opportunity to openly discuss the nature of the problem and engage in problem solving together.

- There are few examples of inclusion of professional process facilitators who can work based on the Danish Model and of more scientific fact-based mediators who are able to provide solid data and reliable analysis of the issues of potential conflicts.

The Danish collective conflict resolution system is an essential part of the 'Danish Model' of labour market regulation. The Danish model has a history of more than 100 years and has proved strong because both parties have accepted the conditions for conflict resolution, which comprise a recognition of conflicts and a mutual support to the 'obligation of peace' as stated in the 'Co-operation agreement'. The social partners play an authoritative role in defining law and regulation, make agreements, and create legitimacy behind the institutions. Further they play an active part as conciliators when resolving conflicts at the workplace level. The Co-operation Agreement' has developed into a type of support system that is based on collective agreements, and work as the first step of the Conflict resolution steps included in the Danish Model.

A key feature of the mediation system is that third party co-operation consultants work together in teams providing mediation services, which installs a joint problem-solving focus in mediation processes at the workplace level. This is different that training individual conflict mediators and relying on individual person's skills and approach to mediation. An interesting new development is the use of more professional process facilitators who can work based on the Danish Model and more scientific fact-based mediators that are able to provide solid data and reliable analysis of the issue of potential conflicts. 
Almost all conflicts are resolved by following 'the norm' for conflict resolution, strikes and lock-outs are rarely occurring. The norm operates as a 'conflict resolution ladder', taking the conflict to the level where it can find it's resolution. Always starting as near the source of the conflict as possible. First resolution at workplace level is supported, then the social partners form a conciliation committee or if not solved at by this take up negotiations on organization level. The next steps are arbitration or finally the Labour Court. An important attribute to this process is that resolution is often gained within a matter of days, even if the Labour Court is involved. This has kept the costs of conflicts to a minimum. The extensive activities of the social partners in the conflict resolution process is also an important tool in an ongoing fine-tuning and adjustment of the collective agreements and the regulation, which preserve the relevance and the applicability of the specific agreements and of the conflict resolution system.

One thing that can impact this system is if the system is threatened from above. Meaning if politicians decide to interfere with the system to regulate a conflict situation. This can create a negative trickle-down effect in the system, in which cooperative institutions and workplace is not given the opportunity to sit down together to share and explain their views to each other about the nature of the problem and how they think it might be resolved.

The Danish model is under pressure from globalization, new sectors with few or no traditions for unionization and political criticism from right wing parties. But so far Labour Unions as well as Employers Organizations have little doubt of the efficiency and the ability of the model to secure a stable Labour market. Currently we even find that new forms of workplace-oriented support are being developed. If the social partners keep up their competences to fast and relevant conflict resolution the model will sustain. However, improving social dialogue an mediation skills and bringing the Danish Model into the future is an ongoing challenge.

\section{References}

Andersen, S. K., \& Mailand, M. (2005). The Danish flexicurity model. The role of the collective bargaining system. Denmark: Employment Relations Research Centre, Department of Sociology, University of Copenhagen.

Blanplain, R. (2007). Decentralizing industrial relations and the role of labor unions and employee representatives. Kluwer Law International.

Danmark Statistik. (2018). Statistics Denmark. Retrieved from: http://www.dst.dk/da/Statistik/ emner/erhvervslivet-paa-tvaers.

Jensen, C. S. (2012). Industrial relations in Denmark: From conflict-based consensus to consensusbased conflict. Copenhagen, Denmark: DJØF Publishing.

Jensen, C. S., Madsen, J. S., \& Due, J. (1993). Towards a European IR-system? The Implications of the Maastricht Treaty for Danish industrial relations. Paper presented at the Third Biennial Conference of the European Community Studies Association (ECSA). Department of Cultural Sociology, FAOS, Industrial Relation Research Group. Copenhagen, Denmark.

Limborg, J. H., Albertsen, K., \& Navrbjerg, S. (2014). m.fl.: Psykisk arbejdsmiljø og samarbejdssystemet inden for LO området. LO-dokumentation nr. 1/2014. 
Mailand, M. (2009). Flexicurity and industrial relations. European Observatory of Working Life. EurWork.

Nationale Arbeidsraad. (1968). Wet van 5 December 1968 betreffende de collectieve arbeidsovereenkomsten en de paritaire comités. Retrieved from Nationale Arbeidsraad: http://www. cnt-nar.be/DOC-DIVERS/Wet-Loi-05.12.1968.pdf.

Navrbjerg, S. E., \& Larsen, T. P. (2014) Dig og den danske model (You and the Danish Model-A handbook for shop stewards). FIU.

Salomon, M. (2000). Industrial relations: Theory and practice. Upper Saddle River, NJ: Prentice Hall.

Samarbejdsnævnet [Coperation Board]. (2006). Co-operation Agreement 2006. Copenhagen, Denmark: The Confederation of Danish Employers and the Danish Confederation of Trade Unions.

Scheuer, S. (1998). Denmark: A less regulated model. In A. Ferner \& R. Hyman (Eds.), Changing industrial relations in Europe. Blackwell: London.

The Danish Labour Court. (2006a). Introduction to the Danish Labour Court. Retrieved from: http:// www.arbejdsretten.dk/generelt/labour-court.aspx.

The Danish Labour Court (2006b). Regler for behandling af faglig strid. Retrieved from: http:// www.arbejdsretten.dk/arbejdsretten/regler/normen.aspx.

Whalen, C. (2008). New directions in the study of work and employment: Revitalizing industrial relations as an academic enterprise. Edward Elgar Publishing.

Open Access This chapter is licensed under the terms of the Creative Commons Attribution 4.0 International License (http://creativecommons.org/licenses/by/4.0/), which permits use, sharing, adaptation, distribution and reproduction in any medium or format, as long as you give appropriate credit to the original author(s) and the source, provide a link to the Creative Commons license and indicate if changes were made.

The images or other third party material in this chapter are included in the chapter's Creative Commons license, unless indicated otherwise in a credit line to the material. If material is not included in the chapter's Creative Commons license and your intended use is not permitted by statutory regulation or exceeds the permitted use, you will need to obtain permission directly from the copyright holder.

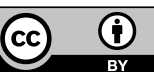

